Sahril: Bahasa Melayu: Antara Barus dan Malaka

\title{
BAHASA MELAYU: ANTARA BARUS DAN MALAKA
}

\author{
Malay Language: Between Barus and Malacca \\ Sahril \\ Balai Bahasa Sumatera Utara \\ Jalan Kolam (Ujung) 7, Medan Estate, Medan, Sumatra Utara \\ sahril1965@gmail.com
}

Naskah masuk: 19 Mei 2020, disetujui: 15 Desember 2020, revisi akhir: 22 Desember 2020

\begin{abstract}
Abstrak
Topik mengenai asal-usul bahasa Melayu sudah diperbincangkan bahkan jauh sebelum NKRI ada. Umumnya, para ahli bersepakat bahwa bahasa Melayu di Nusantara ini berasal dari masa Kerajaan Sriwijaya (Melayu Kuno) dan Kesultanan Malaka untuk bahasa Melayu baru. Kajian ini berusaha membantah pandangan para ahli bahasa tersebut bahwa ada mata rantai yang terputus mengenai jejak awal bahasa Melayu baru, yaitu di Barus, kemudian berkembang di Kerajaan Haru dan Aceh, baru kemudian di Malaka. Teori yang digunakan adalah teori historiografi linguistik untuk melihat sejarah perkembangan bahasa. Metode yang digunakan, yaitu kualitatif mengacu pada pendekatan diakronis. Temuan penelitian menunjukkan bahwa jejak awal bahasa Melayu baru berdasarkan sejarah masuknya Islam ke Nusantara ialah dengan aksara Jawi yang bermula di Barus. Temuan ini membantah pendapat para ahli bahasa yang mengatakan bahwa bahasa Melayu baru bermula di Malaka. Fakta ini didukung oleh karya-karya Hamzah Fansuri pada abad XVI yang menulis karyanya menggunakan bahasa Melayu yang dominan dipengaruhi bahasa Arab dan Persia. Sementara itu, Raja Ali Haji menulis karya, sekitar abad XIX. Bahasa Melayu berkembang di Aceh. Setelah Aceh berhasil ditaklukkan Malaka, barulah bahasa Melayu turut berkembang di Malaka.
\end{abstract}

Kata kunci: Jejak awal bahasa Melayu, bermula di Barus, berkembang di Malaka

\section{Abstract}

Debate and discussion about the origin of the Malay language long before the Republic of Indonesia was discussed. Generally, the opinions of experts agree that the Malay language in the archipelago originated from the Kingdom of Srivijaya (Ancient Malay) and the Malacca Sultanate for the new Malay Language. This study tries to refute the views of the linguists, that there is a broken link regarding the initial traces of the new Malay language, namely in Barus, then developing in the Kingdom of Haru and Aceh, only later in Malacca. The theory used is the theory of linguistic historiography to see the history of language development. The method used is qualitative refers to the diachronic approach. The research findings show that based on the history of the entry of Islam into the archipelago, the initial traces of the new Malay language, namely the Jawi script originated in Barus, so that the opinions of linguists who say say originated in Malacca. This fact is supported by the works of Hamzah Fansuri in the XVI century who wrote his work using Malay which was predominantly influenced by Arabic and Persian languages. While Raja Ali Haji wrote the work, around the XIX century. Malay language developed in Aceh, only after Aceh was conquered by Malacca, the next development in Malacca.

Keywords: The earliest traces of Malay, beginning in Barus, flourished in Malacca

\section{PENDAHULUAN}

Barus bukan saja dikenal sebagai titik nol kilometer peradaban Islam di Nusantara, tetapi dikenal juga sebagai jejak awal bahasa Melayu tumbuh setelah keruntuhan kedigjayaan Kerajaan Sriwijaya. Sejalan dengan Islam masuk ke Nusantara yang diyakini oleh para ahli sejarah bermula di Barus dengan mengacu pada tiga teori kedatangan Islam di Nusantara, yaitu teori Gujarat, teori Mekah, dan teori Persia (Suryanegara 1995). Pertama, teori 
Gujarat, India, menjelaskan bahwa Islam dipercayai datang dari wilayah Gujarat, India, melalui peran para pedagang India muslim pada sekitar abad ke-13 M. Kedua, teori Mekah menjelaskan bahwa Islam dipercaya tiba di Indonesia langsung dari Timur Tengah melalui jasa para pedagang Arab muslim sekitar abad ke-7 M. Ketiga, teori Persia menjelaskan bahwa Islam tiba di Indonesia melalui peran para pedagang asal Persia yang dalam singgah ke Gujarat sebelum ke Nusantara sekitar abad ke-13 M.

Menurut Erawadi (2014:51), keberadaan Barus (Baroussal) telah disebutkan oleh Claudius Ptolemaeus pada abad ke-2 M. Hal ini dipertegas oleh sumber-sumber Cina mulai abad ke-6 $M$ yang selalu menyebut Barus sebagai tempat asal kamfer. Hakim (2019:168) berpendapat bahwa Islam sebelum didakwahkan ke Barus kira-kira abad ke-5 M, sebagai buktinya adalah situs Mahligai, Papan Tinggi, dan makam Tuan Makhdum yang nisannya bertuliskan kaligarafi Alquran. Syekh Mahmud berperan besar dalam memberikan ajaran Islam melalui perdagangan di Kota Barus.

Menurut J.C Van Leur sebagaimana dikutip oleh Hakim (2019:170) berdasarkan berbagai cerita perjalanan, dapat diperkirakan bahwa sejak 674 M ada koloni-koloni Arab di Barus. Melalui peninggalan sejarah di Kota Barus, tentu tidak lepas dari kehidupan manusia sebagai objek dakwah dan penggunaan bahasa sebagai sarana menyampaikan dakwah.

Selanjutnya, sebagaimana Hipotesis Sapir-Whorf yang dikutip Roslina (2005) dalam (Mat \& Sulaiman, 2007:116) menyatakan struktur bahasa yang dituturkan memberikan kesan bagaimana kita membuat tanggapan tentang dunia di sekeliling kita. Jelasnya, tanggapan atau pikiran serta tindakan seseorang bergantung kepada struktur kosakata bahasa yang digunakan, yaitu alat yang digunakannya untuk berpikir dan menanggapi sesuatu.

Cikal bakal bahasa Melayu memang berasal dari masa Sriwijaya yang dominan dipengaruhi oleh bahasa Sanskerta (Mat \& Sulaiman, 2007:117). Hal ini berdasarkan prasasti yang dijumpai di Palembang (7 M), Prasasti Talang Tuwo $(684 \mathrm{M})$, dan di Pulau Bangka (686 M) membuktikan bahwa terdapat kira-kira $70 \%$ kosakata bahasa Melayu kuno dan 30\% lagi kata pinjaman dari bahasa Sanskerta. Kemunduran kerajaan Sriwijaya menyebabkan daerah-daerah taklukannya melepaskan diri dan muncul menjadi kerajaan-kerajaan kecil yang otonom, di antaranya ialah Lamuri, Aru, Pedir, dan Barus (Supriono, 2015:181). Berdasarkan hal tersebut, perkembangan bahasa Melayu banyak dipengaruhi oleh bahasa Arab dan Persia. Hal ini disebabkan oleh kedatangan para penyebar agama Islam di Nusantara melalui Barus. Perkembangan bahasa Melayu yang cukup signifikan adalah setelah kelahiran karya-karya Hamzah Fansuri. Hamzah Fansuri merupakan seorang syekh dan juga sastrawan tasawuf pada abad ke-16. Beliau dilahirkan di Barus dan berkarya di Barus. Akan tetapi, selanjutnya berkiprah di Pasai, Aceh.

Satu hal yang umum disepakati adalah ketokohan Hamzah Fansuri tidak lepas dari konteks Barus. Wilayah itu sering disinggahi para saudagar dan musafir dari mancanegara. Bahkan, Abdulhadi (1995) berpendapat bahwa signifikansi tersebut sudah tercantum dalam naskah sejarah Yunani kuno yang ditulis pada abad kedua sebelum Masehi (SM). Misalnya, catatan Prolomeus yang menyatakan bahwa rombongan kapal Firaun dari Mesir telah berkali-kali berlabuh di Barus untuk mendapatkan kamfer (kapur barus), bahan yang amat diperlukan untuk pembuatan mumi.

Hingga abad ke-16, Barus masih menjadi salah satu tujuan favorit para pedagang dari negeri-negeri jauh. Berbagai komoditas yang bernilai tinggi diperniagakan di sana, misalnya benzoin putih, kamfer, kayu cendana, gaharu, jahe, kayu manis, timah, dan emas. Situasi kota yang kosmopolitan seperti itu memunculkan masyarakat kelas menengah yang haus ilmu pengetahuan. Dapat dipastikan bahwa di Barus pada masa itu telah berdiri lembaga-lembaga pendidikan yang di dalamnya para murid belajar ilmu- 
ilmu agama dan berupaya menguasai berbagai bahasa asing.

Besarnya kiprah Hamzah Fansuri memberinya gelar "Bapak Bahasa dan Sastra Melayu". Sebutan itu boleh jadi tidak berlebihan sebab ulama-sufi itulah yang pertama kali menulis karangan ilmiah dalam bahasa Melayu. Sementara itu, pakar sastra Indonesia, Teeuw (1994), mendaulat Hamzah Fansuri sebagai "Sang Pemula Puisi Indonesia". Tentu saja Indonesia yang dibayangkannya tidak hanya sebatas negara yang diproklamasikan pada 17 Agustus 1945. Teeuw hendak menengahkan bahwa di dalam sajak-sajak Hamzah Fansuri sudah terdapat ciri-ciri kesusastraan modern. Artinya, Hamzah Fansuri memelopori suatu gebrakan kesusastraan di Nusantara jauh sebelum kolonialisme Barat datang.

Di sisi lain, Abdulhadi (1995:11--12) mengaitkan masa hidup Hamzah Fansuri dengan keadaan Barus dengan dinasti Aceh. Pada permulaan abad ke-17, pamor kota tersebut mulai merosot. Penyebabnya adalah bahwa Kerajaan Aceh Darussalam di utara terus berkembang. Para raja berambisi menjadikan Aceh satu-satunya kedaulatan di Pulau Sumatra. Di bawah kepemimpinan Sultan Iskandar Muda (1607-1636), Aceh berhasil menaklukkan Barus. Namun, kota itu tidak dibangunnya sehingga fungsi Barus sebagai pelabuhan dagang kian sepi. Akhirnya, pada awal abad ke-18, wilayah yang sebelumnya ramai itu sudah jarang dikunjungi.

Keberadaan Barus dari segi arkeologi dan sejarah sudah tidak diragukan lagi. Wajar apabila Presiden Joko Widodo meresmikan tugu titik nol kilometer peradaban Islam di Nusantara pada tahun 2017 yang lalu. Sebelumnya, Barus dikenal sebagai daerah penghasil kapur barus (kamfer) yang bernilai tinggi. Semenjak abad ke-2, perdagangan kapur barus sudah berlangsung di Barus. Para saudagar dari belahan dunia berdatangan ke Barus untuk membeli kapur barus. Salah satu kegunaan kapur barus itu adalah untuk mengawetkan jenazah raja-raja Firaun di Mesir.

Belum ada catatan resmi mengenai kapan wilayah Barus terbentuk. Akan tetapi, tercatat sejak abad ke-6 Masehi, rempah-rempah dari Barus menjadi magnet bagi para saudagar dari berbagai penjuru dunia. Dalam buku Lobu Tua Sejarah Awal Barus yang disunting oleh seorang peneliti asal Prancis, Claude Gulliot, Barus juga dikenal dengan nama Pancur atau dalam bahasa Arab menjadi Fansur. Buku yang ditulis oleh beberapa peneliti itu pun belum bisa mengungkap apakah Barus dan Pancur memiliki makna yang sama. Seorang ahli geografi yang juga matematikawan berdarah Yunani, Claudius Ptolemaeus, pada abad ke- 1 Masehi menyebut ada lima pulau yang salah satunya bernama Barousai. Namun, belum terbukti benar apakah Barousai adalah Barus (Guillot, 2002).

Di balik populernya Barus sebagai penghasil kapur barus, tidak banyak yang meneliti bahwa sebenarnya Barus merupakan jejak awal kelahiran bahasa Melayu. Selama ini, para linguis hanya memandang bahwa bahasa Melayu bermula di Malaka. Padahal, ada mata rantai yang terputus antara Barus dan Malaka. Perkembangan bahasa Melayu sebagai lingua franca sangat memungkinkan bermula di Barus karena di sini merupakan tempat melting pot pertemuan berbagai bangsa. Hal tersebut memunculkan bahasa Melayu sebagai bahasa transaksi perdagangan. Berdasarkan ini lah bahasa Melayu disebut sebagai lingua franca.

Studi ini akan melihat sejarah awal jejak bahasa Melayu yang bermula di Barus, berpindah ke Pasai (Aceh), kemudian berlanjut ke Malaka. Tokoh sentral yang memopulerkan bahasa Melayu ialah Hamzah Fansuri.

Berbagai kajian sejarah dan agama mengenai Barus sudah cukup banyak diteliti, di antaranya Hakim (2019), Pinem (2018), Amelia (2017), Azhari (2017), Erawadi (2014), Drakard (2003), Guillot (2002), dan masih banyak lagi, termasuk kajian Barat pada masa silam mengenai Barus. Akan tetapi, kajian yang mengaitkan dengan jejak awal bahasa Melayu sampai saat ini belum ada yang membahas. Selanjutnya, mengenai kajian terhadap Hamzah Fansuri juga sudah cukup 
signifikan jumlahnya. Di antara yang cukup fenomenal, yaitu disertasi Al-Attas (1966), kajian syair perahu Braginsky (1975), dan disertasi Abdulhadi (1995).

Kajian terhadap perjalanan dan sejarah bahasa Melayu telah banyak dilakukan oleh peneliti dari Barat seperti yang dipaparkan Melebek (2006:1-3), di antaranya William Marsden (1754-1836M) yang menghasilkan kajian, yaitu $A$ History of Sumatera (1783), $A$ Dictionary of the Malayan Language (1812), dan A Grammar of the Malayan Language (1812). Rumusan beliau adalah bahasa Melayu dan bahasa Polinesia merupakan bahawa serumpun. Wilhelm Von Humboldt (1767-1835) dalam Uber die Kawisprache Auf des Insel Java (1836) menantang pendapat Crawfurd dan setuju dengan pendapat Marsden. Johan Hendrik Casper Kern (1833-1917) dalam Kawi Studien (1871), Taal Kundige Gegevens Ter Bepaling Van Het Stamland Der Maleisch-Polynesische Volken (1889), beliau mengatakan bahwa bahasa di Asia Tenggara berasal dari tanah besar Asia Tenggara. Reland (1676-1718) mengkaji tentang bahasa Austronesia dan menulis dalam buku berjudul De Linguis Insularum Orientalium. John Reinhold Foster menulis tentang kesamaan bentuk kata antara bahasa Melayu dengan bahasa Polinesia dalam buku berjudul Voyage Around the World. Penelitian lainnya juga dilakukan oleh Wilhelm Schmidt (1868-1954), J.R. Logan, J. Gonda, J.R. Foster, dan lain-lain.

Pendekatan yang digunakan oleh Edward Sapir sejak awal tahun 1920-an berkenaan dengan perkembangan dan pergerakan bahasa secara kronologi sehingga dapat ditelusuri dari kawasan yang memiliki varietas linguistik yang paling besar. Secara teori, ahli linguistik telah menerima pendekatan yang digunakan oleh Edward Sapir untuk menentukan asal-usul dan pergerakan manusia walaupun ada juga pihak yang tidak setuju dengan pendekatan tersebut. Kritik terkait pendekatan tersebut ialah bahwa bahasa mempunyai hubungan atau perkaitan yang jauh disebabkan oleh berbagai bahasa itu sendiri (Peiros, 1998). Seorang ahli linguistik, Sapir (1939), sangat terpengaruh dengan pendekatan yang digunakan oleh Frank Boas, seorang ahli antropologi, yang mengkritik bahwa primitif adalah sama atau setaraf dengan bahasa berbudaya. Boas yang banyak mengkaji tentang budaya masyarakat Asli Amerika membahas bahwa kajian bahasa adalah penting pada disiplin antropologi budaya karena bahasa, budaya, dan masyarakat berkait rapat antara satu sama lain (Sapir, 1968, dan Boas, 1966, dalam Ramli, Z., \& Sulaiman, 2017).

Pendekatan linguistik ini telah digunakan oleh ahli arkeologi bernama Peter Bellwood dalam merekonstruksi kepindahan penutur Austranesia di Asia Tenggara dan dibuktikan dengan data arkeologi terutama jejak-jejak yang mempunyai bukti pertanian dan dalam konteks ini adalah data berkenaan dengan penggunaan tembikar (Bellwood, P \& Sanchez-Mazas, 2005). Berbeda dengan pendekatan HeineGeldern dikutip oleh Ramli, Z., \& Sulaiman (2017:61) yang menggunakan artefak kapak atau beliung batu untuk menunjukkan migrasi penutur Austranesia dari tanah besar Indo-China ke Indonesia. Heine-Geldern yang juga terpengaruh dengan teori yang dikemukakan oleh Schmidt's mengemukakan teori bahwa perpindahan tersebut terjadi sekitar 2500-1500 sebelum Masehi dengan penutur Austronesia membawa budaya Neolitik ke Indonesia. Sementara itu, migrasi kedua terjadi pada 500 SM membawa kebudayaan logam (Heine-Geldern, 1945). Ini secara tidak langsung menunjukkan bahwa kedua ahli arkeologi ini terpengaruh dengan model yang dibentuk oleh ahli linguistik, yaitu Schmidt's dan Robert Blust's.

William Solheim seorang ahli arkeologi telah menggunakan pendekatan arkeologi sepenuhnya dalam melihat penyebaran masyarakat di Asia Tenggara. Beliau melihat penggunaan data artifak tembikar yang bertaburan di jejak Neolitik di Asia Tenggara. Beliau mengutarakan teori (Island Origin) yang juga dikenal sebagai Nusantqo Maritime Trading and Communication West Africa and Madagascar Network (MNTCN) (Solheim, 2000) dalam (Ramli, Z., \& Sulaiman, 2017). 
Stephen Oppenheimer, seorang ahli antropologi, mempunyai pandangan tersendiri berkenaan dengan penyebaran manusia di Asia Tenggara. Beliau menggunakan pendekatan genetik dengan menganalisis mitokondria DNA masyarakat asal di Asia Tenggara dan Pasifik. Analisis tersebut mempunyai tahun yang diperkirakan berdasarkan bidang genetik (Oppenheimer, 1999). Teori yang dikemukakan oleh Oppenheimer ini dinamakan Out of Sundaland. Teori ini mendapat perhatian ahli arkeologi yang mengkaji bidang prasejarah di Asia Tenggara (Ramli, Z., \& Sulaiman, 2017).

Sejak abad ke-16 $M$, pelayar dan pengembara telah mengumpulkan senarai kosakata bahasa Austronesia dari tempat yang pernah mereka singgah. Antonio Pigatetta, seorang pengembara Italia, merupakan orang yang pertama mengumpulkan kosakata bahasa Austronesia ini. Beliau mengikuti ekspedisi Magellan pada tahun 1519--1522. Hadrian Reland (dalam Fox 2004:1) merupakan sarjana Belanda yang pertama pada tahun 1706 mengandaikan ada persamaan antara bahasa Melayu dari kawasan Madagaskar ke Jawa, Borneo, Malaku, hingga ke timur. Menurut Fox (2004), William Von Humboldt juga telah memperkenalkan istilah "Malayo-Polynesian" untuk menunjukkan persamaan bahwa Malayan ke Polinesia. Akan tetapi, istilah tersebut telah digunakan oleh Frank Bopp sebelumnya sebagai istilah dalam kumpulan linguistik (Ramli, Z., \& Sulaiman, 2017:63).

Berdasarkan kajian-kajian terhadap perjalanan bahasa Melayu di atas, penelitian ini menggunakan teori historiografi linguistik. Menurut Kridalaksana (1985) dalam Sariyan (2006), historiografi linguistik atau bisa disebut penyusunan sejarah linguistik merupakan sarana untuk melihat kembali yang telah dilakukan selama ini sehingga diperoleh pemahaman perkembangan konsep, teori, metode, terminologi, dan ciri deskripsi di bidang bahasa. Historiografi linguistik tersebut didasarkan pada pelacakan atas peristiwa masa lalu. Kajian tersebut memerlukan data peristiwa linguistik yang pernah terjadi pada suatu masa dan di suatu tempat karena sejarah tidak pernah lepas dari waktu dan ruang tertentu sekaligus tokoh yang terlibat di dalamnya. Dengan keberadaan historiografi linguistik, kita dapat berusaha memahami perkembangan konsep-konsep, teori, metode, peristilahan dan gaya penyajian dalam bidang bahasa dari dahulu hingga sekarang, atau secara retrospektif, menelusuri konsep-konsep, teori, metode, peristilahan dan gaya penyajian yang lazim pada suatu waktu kepada tradisi yang mungkin menurunkannya.

Historiografi linguistik tidak hanya menggunakan karya-karya teoretis, melainkan juga karya-karya yang dianggap naif atau yang bersifat preskriptif, seperti didapat dalam tata bahasa pedagogis. Terbukti dari perkembangan wawasan tentang bahasa selama ini, yaitu bagaimana masyarakat memandang mengenai bahasa dapat diketahui dari buku. Dari sumber ini, masyarakat membentuk dan mewarisi konsepsikonsepsi tentang bahasa yang dapat dipertanggungjawabkan dari sudut linguistik ataupun tidak (Sariyan, 2006).

\section{METODE PENELITIAN}

Penelitian ini menggunakan pendekatan kualitatif. Pendekatan kualitatif dilakukan untuk membangun pengetahuan melalui pemahaman dan penemuan. Menurut Iskandar (2009:11), pendekatan kualitatif adalah suatu proses penelitian dan pemahaman yang berdasar pada metode yang menyelidiki suatu fenomena sosial dan masalah manusia.

Sementara itu, Mahsun (2005:2) berpendapat bahwa penelitian bahasa merupakan penelitian yang sistematis, terkontrol, empiris, dan kritis terhadap sasaran. Menyikapi hal tersebut, diperlukan metode atau alat bedah untuk memulai penelitian yang sistematis, terkontrol, empiris, dan kritis terhadap sasaran dalam hal pengumpulan data. Metode yang digunakan untuk mengumpulkan data dalam penelitian ini, yaitu metode telaah pustaka dan observasi (Maryam, 2018). Metode telaah pustaka digunakan dengan cara menganalisis teks sejarah masuknya Islam ke Nusantara, sejarah kerajaan- 
kerajaan di Sumatra, karya sastra Melayu, dan kajian arkeologi. Selanjutnya dilakukan observasi ke lapangan untuk melihat artefak-artefak sejarah yang berkaitan dengan sejarah perjalanan bahasa Melayu. Peneliti juga mewawancarai masyarakat adat dan tokoh agama yang ada di Barus.

Sumber lain untuk mendukung data penelitian diperoleh dari buku, artikel jurnal, dan berita terkait sejarah Barus. Berdasarkan sumber-sumber yang diperoleh berkaitan dengan sejarah Barus dipilah-pilah, dikritisi, dan diinterpretasi. Melalui serangkaian metode ilmiah ini, diharapkan akan dapat mengungkap secara objektif bahwa perkembangan bahasa Melayu itu bemula di Barus.

Data dianalisis dengan proses mengatur urutan data, mengorganisasikan ke dalam suatu pola, kategori, dan satuan uraian dasar (Lexy, 2002). Hasil analisis disajikan dengan metode informal. Metode informal digunakan dalam menguraikan hasil analisis data melalui uraian atau secara naratif. Metode informal menurut Mahsun (2005:123) merupakan metode penyajian data dengan cara perumusan menggunakan kata-kata biasa, termasuk terminologi yang bersifat teknis.

Untuk menelusuri sejarah perjalanan bahasa Melayu, digunakan pendekatan linguistik diakronis. Verhaar (1984:6) menyitir sebuah istilah dari Saussure mengenai linguistik diakronis adalah penyelidikan tentang perkembangan suatu bahasa. Misalnya, bahasa Indonesia sekarang berlainan dari bahasa Melayu klasik serta berlainan pula dari bahasa Melayu kuno yang tertulis pada prasastiprasasti Kedutaan Bukit, Talang Tuwo, dan Kota Kapur. Bahasa Melayu kuno memiliki awalan mar- yang dalam bahasa Melayu klasik dan dalam bahasa Indonesia menjadi me- dan ber-. Bandingkan bahasa Inggris sebelum tahun 1000 sesudah masehi dengan bahasa Inggris sekarang, akan tampak bahwa sebagian besar dari akhiran telah hilang. Perubahan semacam itu terjadi secara tidak kebetulan, melainkan menurut hukum perkembangan tertentu.

Menurut Chaer (2007), Ferdinand de Saussure (1857--1913) adalah Bapak Linguistik Modern yang mengarang Course de Linguistique Generale. Dalam buku tersebut, disimpulkan empat gagasan penting sebagai berikut.

1) Bahasa dapat ditelaah secara sinkronik, yaitu diteliti berdasarkan kurun waktu penggunaan pada zaman tertentu. Selain itu, bahasa juga dapat ditelaah secara diakronik, yaitu sebuah bahasa yang diteliti dari sejarah penggunan hingga masa kini.

2) Perbedaan mengenai Langue dan Parole. Langue adalah keseluruhan sistem tanda bersifat abstrak yang digunakan sebagai alat komunikasi verbal antarmanusia. Sementara itu, parole adalah realisasi dari langue yang bersifat konkret dan dapat diamati.

3) Bahasa mengandung sistem tanda linguistik yang bernama signifiant dan signifie. Signifiant adalah kesan bunyi yang timbul dalam benak manusia, sedangkan signifie adalah kesan makna yang merujuk pada objek yang dimaksud.

4) Elemen bahasa seperti fonem, morfologi, dan sintaksis memiliki hubungan yang dinamakan Sintagmatik dan Paradigmatik.

Linguistik diakronis menurut Chaer (2007:14) berupaya mengkaji bahasa (atau bahasa-bahasa) pada masa yang tidak terbatas, bisa sejak awal kelahiran bahasa itu sampai zaman kepunahan bahasa tersebut (kalau bahasa tersebut sudah punah, seperti bahasa Latin dan bahasa Sansekerta), atau sampai zaman sekarang (kalau bahasa itu masih tetap hidup, seperti bahasa Jawa dan bahasa Arab). Sementara itu, Pateda (1988:48) berpendapat bahwa linguistik diakronis ingin mempersoalkan, menguraikan, atau menyelidiki perkembangan bahasa dari masa ke masa. Linguistik diakronis dapat juga disamakan dengan linguistik historis sehingga bersifat vertikal.

Chaer (2007) dan Pateda (1988) menjelaskan ciri-ciri linguistik diakronik, yaitu (1) menelaah bahasa tanpa ada batasan waktu; (2) bersifat vertikal karena melakukan perbandingan bahasa dari masa ke masa; (3) bersifat historis dan komparatif; dan (4) perkembangan dan 
perubahan struktural bahasa dapat diketahui secara jelas.

\section{HASIL DAN PEMBAHASAN}

Beberapa peneliti mengaitkan tulisan (aksara) yang pernah ada sebelum aksara Jawi digunakan di Nusantara, walaupun sulit menyebutkan sumber-sumber yang ada. Apabila dikaitkan dengan penelitian di bidang bahasa dan tulisan Jawi, masih sedikit dengan para ahli sastra dan sejarah dalam ruang lingkup Melayu. Menurut Hermansyah (2014:34) beberapa ahli yang menggeluti bahasa Melayu di antaranya, Hendrik Kern (Belanda) dan Robert von Heine Geldern (Austria) telah mendalami bahasa dan sosial masyarakat Melayu kuno. Kesimpulan besar mereka menyebutkan silsilah keturunan Melayu yang berkembang sekarang ini berasal dari Melayu-Deutro, yaitu dari kelompok Austronesia.

Ahli bahasa membagi perkembangan bahasa Melayu ke dalam tiga tahap utama, yaitu: (1) Bahasa Melayu kuno (abad ke-7 hingga abad ke-13), (2) Bahasa Melayu klasik, mulai ditulis dengan huruf Jawi (sejak abad ke-15), dan (3) Bahasa Melayu modern (sejak abad ke-20) beraksara Latin (Collins, 2005). Penulis menggolongkannya (1) Bahasa Melayu kuno pada masa kedigjayaan Kerajaan Sriwijaya (abad 713), beraksara Sanskerta/Pallawa, (2) Bahasa Melayu Jawi, beraksara Jawi/arab gundul (abad 15-19) dimulai oleh Hamzah Fansuri di Barus hingga Raja Ali Haji di Penyengat, (3) Bahasa Melayu modern (abad 20), dengan aksara Latin, dimulai oleh Van Ophuijsen (Indonesia) dan Wilkinson (Malaka).

Peralihan bahasa Melayu kuno ke bahasa Melayu Jawi dikaitkan dengan pengaruh agama Islam yang semakin kuat di Nusantara pada abad ke-13. Selepas itu, bahasa Melayu mengalami banyak perubahan dari segi kosakata, struktur kalimat dan tulisan.

Terdapat tiga prasasti yang penting, yaitu di Pagar Ruyung, Minangkabau (1356), ditulis dalam aksara Sanskerta, mengandung prosa Melayu kuno dan beberapa baris sajak Sanskerta, bahasanya berbeda sedikit dari bahasa prasasti abad ke-7; Prasasti di Minye Tujuh, Aceh (1380), masih memakai aksara Sanskerta, untuk pertama kali terdapat penggunaan katakata Arab seperti kalimat Nabi, Allah dan Rahmat; Prasasti di Kuala Berang, Trengganu (1303-1387), ditulis dalam aksara Jawi. Ketiga prasasti ini merupakan bukti catatan terakhir perkembangan bahasa Melayu karena pada abad ke-14, muncul kesusasteraan Melayu dalam bentuk tulisan yang dipelopori oleh Hamzah Fansuri di Barus.

Terdapat bermacam pendapat istilah 'Melayu'. Al-'Attas, dikutip Hermansyah (2014:34-35) dalam Kitab Adat Melayu, menyatakan bahwa kemunculan istilah 'Melayu' dimulai dengan kepindahan sang Sapurba dari Palembang ke Bintan. Terdapat sungai kecil berarus deras yang alirannya diistilahkan dengan nama tanah Melayu. Sementara itu, Van der Tuuk menganggap kata 'Melayu' berarti 'penyeberang', yaitu ke agama Islam.

Sebelum tulisan Arab muncul di tanah Melayu, beberapa peneliti mengungkapkan telah berkembang tulisantulisan yang beragam di berbagai wilayah di Nusantara dan Asia Tenggara. Hal ini dipengaruhi oleh Hindu dan Budha. Tulisan yang digunakan oleh orang-orang Melayu sebelumnya, yaitu tulisan rencong atau runcing di Sumatra, tulisan Kawi di tanah Jawa dan tulisan-tulisan lain yang digunakan di Filipina, Sulawesi, dan beberapa tempat lain di Asia Tenggara (Chaer, 2007:82). Al-Attas (dalam Hermansyah, 2014:34) menyebutkan bahasa Melayu sebelum kehadiran Islam juga berasal dari rumpun bahasa Austronesia. Kemudian, turunan terbagi pada beberapa bahasa, seperti bahasa Polinesia, bahasa Melanesia, bahasa Nusantara, dan bahasa Mikronesia. Bahasa Nusantara atau juga disebut dengan bahasa Kepulauan Melayu, di antaranya bahasa Melayu, Aceh, Jawa, Sunda, Dayak, Solo, Roto Sika, dan lain sebagainya. Keberagaman keseluruhan bahasa Nusantara dipastikan lebih dari seratus bahasa dari berbagai daerah dan dialek yang berbeda.

Hermansyah (2014:35) berpendapat bahwa para ahli Barat sangat 
memfokuskan kajian tentang bahasa Melayu dan kesusateraan, di antaranya Pigafetta (Italia) bersama Magellan telah menyusun kamus Melayu-Italia dalam pelayaran saat ke Tidore pada tahun 1521 . Selain itu, Jan Hugen van Linschotten asal Belanda sebagai staf pemerintah Portugis tahun 1586--1592 dalam catatannya menyebutkan bahasa Melayu sebagai bahasa resmi di negeri Timur dan seluruh kepulauan di Asia Tenggara. Ungkapan yang sama juga diutarakan oleh Francios Valentijn, orientalis yang banyak mengkaji sejarah kepulauan Melayu awal abad ke18.

Selanjutnya, Abdulhadi (1995) mengutip keterangan François Valentijn, seorang misionaris Belanda yang berkunjung ke Barus pada 1706. Di dalam catatannya, beliau mengagumi keindahan bahasa Melayu dan memuji Hamzah Fansuri sebagai "seorang yang sangat terkemuka di lingkungan orang-orang Melayu karena syair-syair dan puisi-puisinya yang menakjubkan". Oleh karena itu, Hamzah Fansuri masih mengalami zaman akhir kegemilangan Kota Barus sekaligus menyaksikan pula ekspansi Aceh Darussalam pada masa hayat.

Pada 1856, Herman Neubronner Van der Tuuk, seorang ahli bahasa dari Belanda, melakukan sebuah pengamatan di Barus. Dalam laporannya, Van der Tuuk menyebut wilayah pantai barat Barus, terutama di Keresidenan Tapanuli, dikuasai oleh orangorang Tionghoa dan Koromandel (orang Keling). Mereka mendominasi sebagian besar sektor perdagangan (Tuuk, 1856).

Penelitian Van der Tuuk itu membuka fakta bahwa Barus tidak hanya dihuni oleh orang Batak dan Melayu, tetapi juga banyak suku bangsa yang membangun peradaban di sana. Bahkan, masyarakat Tionghoa terbilang baru apabila dibandingkan dengan orang Tamil (Keling) yang telah membangun permukiman berabad-abad sebelumnya. Drakard (2003) mengatakan bahwa kemajuan Barus banyak disebabkan oleh orang-orang India. Barus, baik yang ada dalam dokumen para pedagang Tionghoa maupun daerah sekarang, telah ada sebelum abad ke-8 M. Wilayah Barus meliputi satu daerah luas di utara Sumatra. Pelabuhan Barus terletak di bagian timur laut Sumatra, di antara Aceh dan Tanjung Intan, menghadap langsung Selat Malaka (Wolters, 2017). Pendapat ini menunjukkan bahwa saat itu wilayah Kerajaan Barus meliputi Selat Malaka. Berdasarkan pendapat Wolters ini, dapat dipastikan bukan Malaka yang menjadi titik awal perkembangan bahasa Melayu, tetapi Barus yang menjadi jejak awalnya.

Hasil penelitian Collins (2005) menunjukkan bahwa bahasa Melayu hingga kini melewati lima tahapan periodisasi, mulai dari periode prasejarah (sebelum abad ke-7), periode awal bahasa Melayu (abad ke-7 hingga abad ke-16), periode awal bahasa Melayu modern (abad ke-16 hingga abad ke-18), periode akhir bahasa Melayu modern (abad ke-18 hingga awal abad ke-20), hingga periode bahasa Melayu pascakolonial (pertengahan abad ke-20).

Khusus terkait pengaruh bahasa Arab ke dalam bahasa Melayu, hipotesis Johns (Chambert-Loir, 2009:51) yang menyatakan bahwa "penerjemahan" bahasa Arab ke dalam bahasa Melayu mengalami empat tahap. Johns membagi tahap "penerjemahan" bahasa Arab dalam bahasa Melayu ke dalam empat tahap: (1) penerjemahan lisan kutipan-kutipan pendek Al-Quran ke dalam bahasa setempat; (2) terjemahan antarbaris dan catatan pinggir dalam bahasa Melayu; (3) terjemahan antarbaris lengkap bagi seluruh teks; (4) karya asli berbahasa Melayu berdasarkan khasanah Arab dari wacana Islam.

Perkembangan paling penting bahasa Melayu terjadi pada periode 1530-1880. Setelah kedigjayaan Sriwijaya runtuh, kerajaan-kerajaan Melayu ganti menguat. Selepas Palembang berjejak di Barus abad ke-16 lanjut ke Aceh, perkembangan bahasa Melayu terus berkembang. Karyakarya Hamzah Fansuri membuktikan bahwa bahasa Melayu sudah mulai digunakan dalam karya sastra, khususnya syair.

Sebagaimana tujuan penelitian adalah berupaya menepis tiga teori yang dikemukakan tentang asal-usul penutur bahasa Melayu, atau bentuk awalnya 
sebagai anggota bahasa-bahasa Dayak Malayik (Adelaar, 1988). Sementara itu, Hudson (1970) melontarkan teori asal dari Kalimantan berdasarkan kemiripan bahasa Dayak Malayik (dituturkan orang-orang Dayak berbahasa Melayu) dengan bahasa Melayu kuno. Penuturnya yang hidup di pedalaman dan karakter kosakata yang konservatif (Nasanius, 2007). Sementara Kern (1888) (dalam Proudfoot, 1993) beranggapan bahwa tanah asal penutur bahasa Melayu adalah dari Semenanjung Malaya dan menolak Kalimantan sebagai tanah asal.

Sejalan dengan pendapat yang menolak teori tersebut, penulis juga berpandangan demikian. Pendapat ini jelas tidak masuk akal jika melihat bukti pada Prasasti Kedukan Bukit, Palembang (bertahun 605 Saka). Dalam prasasti tersebut, Dapunta Hyang melakukan perjalanan suci ke timur dengan membawa dua laksa tentara. Pada abad ke-5 M, berdiri sebuah kerajaan di Kalimantan Selatan bernama Kerajaan Tanjungpuri. Berdirinya kerajaan ini bermula dari kedatangan para imigran Melayu dari Kerajaan Sriwijaya pada sekitar abad ke-4 M. Para imigran Melayu yang mempunyai kebudayaan lebih maju dibanding penduduk lokal pada masa itu mendirikan perkampungan kecil di daerah pesisir Sungai Tabalong. Hal ini diperkuat bahwa Prasasti Batung Batulis di Kalimantan bertahun 606 Saka. Hal ini sejalan dengan temuan Harimurti Kridalaksana berdasarkan penelitian leksikostatistik yang menyimpulkan bahwa muasal bahasa Melayu Kuno dari Sumatra. Hasil dari penelitian ini mempertimbangkan dialek regional bahasa Melayu terbanyak ditemukan di Sumatra.

Menurut Thurgood (1996), beberapa pakar seperti Marrison (1975), Adelaar (1985), dan Collins (2005) turut mengemukakan hubungan istimewa antara bahasa Champa dan Melayu. Adelaar (1988) dan Bellwood (1993) menyatakan bahwa teori ini sempat diterima cukup lama karena sejalan dengan teori migrasi dari Asia Tenggara daratan. Hingga akhirnya, bukti-bukti linguistik dan sejarah menyangkal hal ini pada akhir abad ke-20 sehingga teori asal dari Sumatra yang menguat, berdasarkan bukti-bukti tulisan. Begitu juga beberapa penelitian dari Barat mengklaim bahwa selepas masa Sriwijaya, catatan tertulis tentang bahasa Melayu baru muncul semenjak masa Kesultanan Malaka (abad ke-15).

Laporan Portugis dari abad ke-16 menyebut mengenai penguasaan bahasa Melayu untuk transaksi perdagangan. Seiring dengan keruntuhan kekuasaan Portugis di Malaka dan kemunculan berbagai kesultanan di pesisir Semenanjung Malaya, Sumatera, Kalimantan, serta Selatan Filipina, dokumen-dokumen tertulis di kertas dalam bahasa Melayu mulai ditemukan. Suratmenyurat antarpemimpin kerajaan pada abad ke-16 juga diketahui telah menggunakan bahasa Melayu. Mereka menggunakan bahasa Melayu yang "disederhanakan" dan mengalami percampuran dengan bahasa setempat karena mereka bukan penutur asli bahasa Melayu. Bahasa ini lebih populer sebagai bahasa Melayu Pasar (Bazaar Malay). Pandangan ini perlu diperjelas bahwa sebelum kerajaan-kerajaan Melayu di Pesisir Timur Sumatra berdiri, bahkan sebelum Kesultanan Malaka berdiri, telah berdiri suatu Kerajaan di Barus. Kota Barus menjadi pusat perdagangan internasional. Para pedagang dari jazirah Arab sudah mengunjungi Barus untuk membeli kapur barus (kamfer) dan kemenyan (Guillot, 2002).

Diperkuat lagi dengan sejarah Islam masuk ke Nusantara. Purwanto (2002:290) berpendapat bahwa perkampungan Arab sudah ada di wilayah Nusantara pada abad ke-7. Hal ini berarti semenjak masa khalifah Rasyidin, orang Arab muslim sudah melakukan perdagangan ke Nusantara. Terbukti di daerah Barus sudah ada pedagang Arab melakukan perdagangan pada abad ke-7 atau 1 Hijriyah.

Berdasarkan cerita perjalanan pengembara yang pernah sampai ke Asia Tenggara, Helmiati (2011: 5) menuliskan pendapat dari J.C. van Leur bahwa sejak tahun $674 \mathrm{M}$ sudah ada koloni-koloni Arab di Barus. Tjandrasasmita (2002:9), Daerwis (2003:30), dan Yatim (2010:194) 
menyatakan bahwa dalam catatan Cina masa Dinasti Tang yang menyebut orang Arab-Persia itu "Ta-Shih". Pada abad 9--10 M, orang Arab sudah ada di Kanton (Kan$f(u)$.

Skenario yang dibuat oleh peneliti lain merumuskan bahwa rintisan bahasa Melayu modern dimulai ketika Raja Ali Haji, sastrawan istana dari Kesultanan Riau Lingga, secara sistematis menyusun kamus ekabahasa bahasa Melayu (Kitab Pengetahuan Bahasa, yaitu Kamus Loghat Melayu-Johor-Pahang-Riau-Lingga penggal yang pertama) pada pertengahan abad ke19. Peneliti lain juga mengatakan bahwa bahasa yang dipakai pada penerbitan buku-buku oleh Balai Pustaka telah meninggalkan induk bahasa Melayu, yaitu Melayu Riau. Pandangan ini perlu dipertegas bahwa sebutan untuk bahasa Melayu modern adalah bahasa Melayu yang beraksara Latin. Jika mengacu pada karya Raja Ali Haji, beliau masih menulis dalam aksara Jawi sama jauh sebelumnya seperti yang dilakukan oleh Hamzah Fansuri. Justru jejak awal bahasa Melayu modern yang berakara Latin itu dipelopori oleh Van Ophuijsen yang menulis kitab logat Melayu dibantu oleh dua orang dari pribumi, yaitu Nawawi Soetan Ma'moer dan Moehammad Toib Soetan Ibrahim. Van Ophuijsen kala itu menjadi guru di Kweekschool Padangsidimpuan, Sumatera Utara. Setelah Kitab Logat Melayu Woordenlijst voor de spelling der Malaisch taal met Latijnch karakter diterjemahkan oleh T.W Kamil, Buku Tata Bahasa Melayu yang disusun oleh Van Ophuijsen yang akhirnya menjadi pedoman dalam berbahasa Melayu di Indonesia. Perlu diketahui bahwa pengaruh Van Ophuijsen terhadap bahasa Melayu di Barus sangat besar. Jarak antara Barus dan Padangsidimpuan hanya sekitar 70 kilometer. Walaupun di saat Van Ophuijsen menulis kitab logat Melayu, kondisi Barus sebagai pusat perdagangan sudah tidak ada lagi. Akan tetapi, penggunaan bahasa Melayu dialek Barus dapat ditemukan pada masyarakat Siladang di Kota Panyabungan (sampai saat ini), sekitar 55 kilometer dari Padangsidimpuan.

Perkembangan selanjutnya ketika bahasa Melayu telah ditulis dengan huruf Latin. Bahasa Melayu dipakai untuk pengajaran di sekolah-sekolah. Bahasa Melayu dengan akrasa Latin karya Van Ophuijsen ini kemudian dikenal luas oleh kalangan orang-orang pribumi dan mulai dianggap menjadi identitas kebangsaan Indonesia. Puncaknya adalah ketika dalam Kongres Pemuda II (28 Oktober 1928) dengan jelas menyatakan "menjunjung bahasa persatuan, bahasa Indonesia". Sejak saat itu, bahasa Melayu diangkat menjadi bahasa kebangsaan walaupun pada Kongres Pemuda I 1926 terjadi perdebatan panjang antara Muhammad Tabrani didukung Sanusi Pane dengan Muhammad Jamin didukung Jamaluddin Adinegroho yang mempersoalkan nama bahasa persatuan itu. M. Jamin dan Jamaluddin Adinegroho memilih penamaan 'bahasa Melayu' karena tidak ada bahasa Indonesia. Sementara itu, M. Tabrani dan Sanusi Pane mengatakan apabila tidak ada bahasa Indonesia, marilah kita lahirkan agar sejalan dengan butir pertama dan kedua naskah sumpah pemuda itu.

Untuk memperkuat alasan bahwa bahasa Melayu itu mula berjejak di Barus sekaligus untuk membantah pandangan ahli bahasa di atas, penulis membuat bagan asal mula bahasa Melayu di Nusantara yang berjejak di Barus serta membantah apa yang dikeluarkan oleh WordTips yang menggambarkan peta perjalanan bahasa Austronesia (dalam 100 bahasa yang paling banyak digunakan di dunia). 
Gambar 1: Perjalanan Bahasa Austronesia

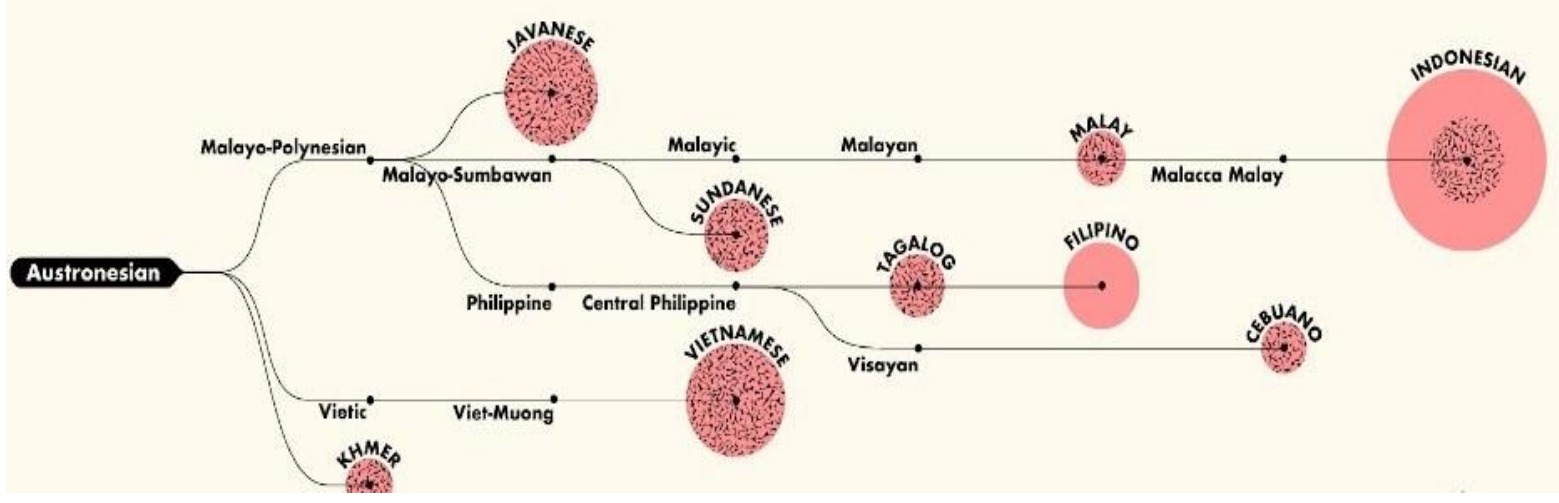

Gambar di atas jelas menunjukkan bahwa bahasa Indonesia merupakan turunan dari bahasa Melayu Malaka. Hal ini sangat bertentangan dengan kenyataan yang ada.

Bagan 1: Teori Kedatangan Islam ke Nusantara dan Asal Bahasa Melayu

\section{Teori Kedatangan Islam ke Nusantara dan Asal Bahasa Melayu}

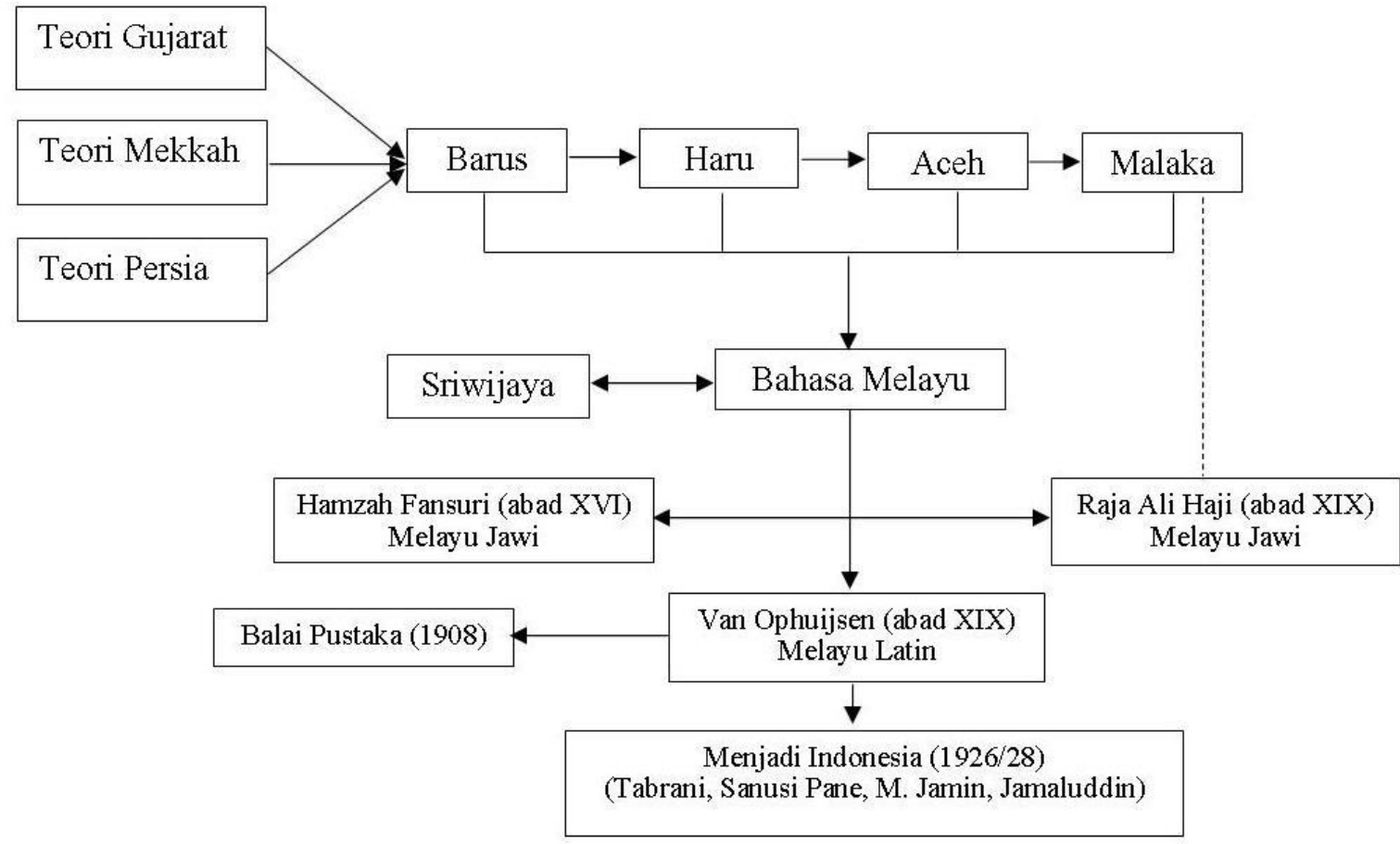

Berdasarkan bagan di atas, dapat dijelaskan bahwa bahasa Melayu setelah keruntuhan Kerajaan Sriwijaya banyak dipengaruhi Islam ke Nusantara. Dari tiga teori Islam masuk ke Nusantara itu, semuanya mendarat awal sekali di Barus, selanjutnya singgah di Kerajaan Haru
(Deli), baru kemudian berkembang di Aceh dan Malaka. Bahasa Melayu ini berakar dari bahasa Melayu yang pernah ada pada masa Sriwijaya. Bahasa Melayu kala itu berkembang melalui aksara Jawi (arab gundul) yang dipelopori oleh Hamzah Fansuri pada abad ke-16. Apabila mengacu 
pada peran Raja Ali Haji yang juga menulis dalam aksara Jawi baru bermula pada abad ke-19, yang dominan terpengaruh dari perkembangan bahasa Melayu dari Malaka. Kemunculan Van Ophuijsen sebagai pertama sekali menulis bahasa Melayu dalam aksara Latin. Sebagai embrio bahasa Indonesia, pada masa Van Ophujisen berdirilah Commissie voor de Volkslectuur atau Komisi untuk Bacaan Rakyat yang akhirnya menjadi Balai Pustaka yang banyak melahirkan karya-karya sastra. Saat itu dikenal bahasa Melayu Balai Pustaka. Pada saat hendak di-Indonesiakan, tokoh-tokoh bangsa kita mengambil bahasa Melayu Balai Pustaka itu menjadi bahasa persatuan bahasa Indonesia, bukan berasal dari bahasa Melayu tinggi Riau yang selama ini kita ketahui.

Bukti yang kuat untuk menyimpulkan bahwa asal mula bahasa Melayu itu berjejak dari Barus dapat dilihat pada karya-karya Hamzah Fansuri (meninggal $1560 \mathrm{H}$ ). Hamzah Fansuri menulis karyanya sekitar abad ke-16 M, ditulis dalam bahasa Melayu beraksara Jawi. Berikut dikutip lima bait syair Hamzah Fansuri yang ditulis beliau semasa berada di Barus.

Hamzah miskin orang 'uryani seperti Isma 'il jadi qurbani

bukannya 'ajami lagi 'arabi

nentiasa washil dengan yang baqi

unggas itu terlalu pingai

warnanya sempurna bisai

rumahnya tiada berbidai

duduknya da'im di balik tirai

suluhnya terlalu terang

harinya tiada berpetang

jalannya terlalu henang

barang mendapat dia terlalu menang

hamzah nin 'ilmunya zhahir ustadhnya sayyid 'abd al-qadir mahbubnya terlalu hadir dengan dirinya 'nantiasa satir

arasy allah akan pangkalannya

habib allah akan taulannya

bayt allah akan sangkarannya

menghadap tuhan dengan sopannya

Melihat bentuk dan bahasa Melayu yang digunakan, wajar saja jika A Teeuw mendaulat Hamzah Fansuri sebagai "Sang Pemula Puisi Indonesia". Selanjutnya, dapat pula kita lihat karya Raja Ali Haji (1809-1870) yang sangat fenomenal, yaitu Gurindam Duabelas yang ditulis pada abad ke-19. Berikut kutipan Gurindam Duabelas pasal yang pertama yang ditulis pada tahun $1263 \mathrm{H}$ atau $1842 \mathrm{M}$.

Barang siapa tiada memegang agama, Sekali-kali tiada boleh dibilangkan nama.

Barang siapa mengenal yang empat,

Maka ia itulah orang yang ma'rifat

Barang siapa mengenal Allah,

Suruh dan tegahnya tiada ia menyalah.

Barang siapa mengenal diri,

Maka telah mengenal akan Tuhan yang bahri.

Barang siapa mengenal dunia,

Tahulah ia barang yang teperdaya.

Barang siapa mengenal akhirat,

Tahulah ia dunia mudarat.

Jika melihat dari dua tokoh sastra fenomenal ini, keduanya menggunakan bahasa Melayu dalam menulis karyanya. Dalam hal ini, jelas bahwa Hamzah Fansuri sudah lebih dahulu menggunakan bahasa Melayu bila dibandingkan Raja Ali Haji. Oleh karena itu, dapat disimpulkan bahwa asal mula bahasa Melayu itu berjejak di Barus.

Di Barus, ada sebuah desa yang bernama Kampung Mudik. Lokasinya persis di samping Sungai Aek Sirahar yang berhilir langsung ke laut samudra Indonesia. Konon, menurut informan, (saat penulis melakukan penelitian) di kampung inilah tempat bermukim Hamzah Fansuri. Menurut keterangan informan yang juga tokoh masyarakat Barus, saat Hamzah Fansuri pergi belajar menuntut ilmu ke beberapa negara di jazirah Arab, lalu pulang ke tanah air melalui Barus dan kapalnya bersandar di Sungai Aek Sirahar, saat itu Hamzah Fansuri menyebut tempat ini sebagai tempat dia mudik. Jadi, istilah mudik itu sudah ada semenjak Hamzah Fansuri. Akhirnya, masyarakat menamakan kampung itu dengan Kampung Mudik. Di kampung ini juga awalnya bertapak para ulama kelahiran Barus maupun ulama yang berasal dari jazirah Arab. Hal ini dapat diterima akal karena jarak antara Kampung Mudik dengan kompleks Pemakaman Mahligai hanya berjarak lebih kurang satu kilometer saja. Di kompleks Pemakaman 
Mahligai ini bersemanyam pusara salah seorang ulama, yaitu Syekh Rukunuddin yang wafat pada 13 Syafar 48 Hijriah. Di atas Sungai Aek Sirahar saat ini telah dibangun sebuah jembatan megah yang diberi nama Jembatan Hamzah al-Fansuri.

\section{SIMPULAN}

Konklusi umum diketahui bahwa bahasa Melayu berasal dari Malaka. Beberapa teori oleh para peneliti Barat mengungkapkan muasal bahasa Melayu. Ada yang menyimpulkan berasal dari Kalimantan, Malaka, dan Sumatra. Tinjauan ahli linguistik, tidak satu pun yang menunjukkan berasal dari Barus. Akan tetapi, berdasarkan penelitian arkeologi, sejarah, karya sastra, dan masuknya Islam ke Nusantara, semuanya bermuara ke Barus. Bahkan, temuan terbaru dari WordTips mengatakan bahwa bahasa Indonesia sendiri berasal dari bahasa Melayu Malaka. Hal ini sangat menyakitkan bagi bangsa Indonesia sebab berdasarkan temuan itu seakan bahasa Indonesia adalah subbahasa Melayu Malaka. Bahasa Indonesia tersubordinasi oleh bahasa Melayu Malaka (Malaysia).

Berdasarkan penelitian yang telah dilakukan, ternyata ada mata rantai yang terputus antara Barus dan Malaka. Justru kenyataan historis yang didukung fakta arkeologi, sejarah, dan karya Hamzah Fansuri menunjukkan bahwa jejak awal bahasa Melayu itu di Barus, selanjutnya berkembang biak di Aceh (Pasai). Baru kemudian setelah takluknya Aceh oleh Malaka, perkembangan selanjutnya adalah di Malaka.

\section{DAFTAR PUSTAKA}

Abdulhadi, W. (1995). Hamzah Fansuri: Risalah Tasawuf dan Puisi-puisinya. Bandung: Mizan.

Abdulhadi, W. (2016). Cakrawala Budaya Islam. Yogyakarta: IRCiSoD.

Adelaar, K. . (1988). More on ProtoMalayic. In M. T. A. \& Z. M. Zain (Ed.), Rekonstruksi dan cabang-cabang Bahasa
Melayu induk. Seri monograf sejarah bahasa Melayu (pp. 59-77). Kuala Lumpur: Dewan Bahasa dan Pustaka.

Adelaar, K. A. (1985). Proto-Malayic: the reconstruction of its phonology and parts of its lexicon and morphology. Offsetdrukkerij Kanters.

Al-Attas, S. M. N. (1966). The Mysticism of Hamzah Fansuri. University of London.

Amelia, P. (2017). Pengelolahan Warisan Budaya Kawasan Barus. Universitas Gadjah Mada.

Azhari, I. (2017). "Politik Historiografi" Sejarah Lokal: Kisah Kemenyan dan Kapur Dari Barus, Sumatera Utara. Sejarah dan Budaya: Jurnal Sejarah, Budaya, dan Pengajarannya. https://doi.org/10.17977/um020v11i1201 7p009

Bellwood, P \& Sanchez-Mazas, A. (2005). Human migrations in Continental East Asia and Taiwan: Genetic, Linguistic and Archacologied evidence. Current Anthropology, 46(3), 480-484.

Bellwood, P. (1993). Cultural and biological differentiation in peninsular Malaysia: the last 10,000 years. Asian Perspectives, 32, 37-60.

Boas, F. (1966). Introduction to the Handbook of American Indian Languages. Lincoln: University of Nebraska Press.

Braginsky, V. Y. (1975). Some Remarks on The Structure of The "Syair Perahu" by Hamzah Fansuri. Bijdragen Tot de Taal-, Land-En Volkenkunde, (4de AfI), 407426.

Chaer, A. (2007). Linguistik Umum. Jakarta: Rineka Cipta.

Chambert-Loir, H. (2009). Sadur: Sejarah Terjemahan di Indonesia dan Malaysia. (H. Chambert-Loir, Ed.). Jakarta: Kepustakaan Populer Gramedia. 
Collins, J. T. (2005). Bahasa Melayu, Bahasa Dunia: Sejarah Singkat. Jakarta: Yayasan Obor Indonesia.

Daerwis, Y. (2003). Sejarah Perkembangan Pers Minangkabau (1859-1945). Jakarta: PT. Gramedia Utama.

Drakard, J. E. (2003). Sejarah raja-raja Barus: dua naskah dari Barus. Jakarta: Gramedia Pustaka Utama, Ecole Francaise d'Extreme-Orient.

Erawadi. (2014). Melacak Jejak-jejak Peradaban Islam di Barus. HIKMAH, $8(01), 41-52$.

Fox, J. J. (2004). Current developments in comparative Austronesian studies. Paper presented for International Symposium Austronesia III, Pascasarjana Linguistik dan Kajian Budaya, Universitas Udayana, Benpasar, Bali. In Paper presented for International Symposium Austronesia III, Pasca Sarjana Linguistik dan Kajian Budaya. Denpasar, Bali.: Universitas Udayana.

Guillot, C. (2002). Lobu Tua, Sejarah Awal Barus (Vol. 1). Jakarta: Yayasan Obor Indonesia.

Hakim, U. F. R. (2019). Barus sebagai Titik Nol Islam Nusantara: Tinjauan Sejarah dan Perkembangan Dakwah. Jurnal IImiah Syíar. https://doi.org/10.29300/syr.v19i2.2469

Helmiati. (2011). Sejarah Islam Asia Tenggara. Pekanbaru: Zanafa Publishing.

Hermansyah. (2014). Kesultanan Pasai Pencetus Aksara Jawi (Tinjauan NaskahNaskah di Nusantara). Jumantara, 5(2), 27-51.

Hudson, A. . (1970). A note on Selako: Malayic Dayak and Land Dayak languages in West Borneo. Sarawak Museum Journal, 18, 301-318.

Iskandar, D. (2009). Metodologi Penelitian Kualitatif. Jakarta: Gaung Persada.
Lexy, J. M. (2002). Metodologi penelitian kualitatif. (R. Rosdakarya, Ed.). Bandung.

Mahsun. (2005). Metode Penelitian Bahasa: Tahapan, Strategi, Metode, dan Tekniknya. Jakarta: PT Raja Grafindo Persada.

Marrison, G. E. (1975). The early Cham language, and its relationship to Malay. Journal of the Malaysian Branch of the Royal Asiatic Society, $48(2$ (228)), 52-59.

Maryam, S. (2018). Konstruksi Pemberitaan Isu Terorisme pada Media Massa: Tinjauan Imagologi dan Linguistik Kritis dan Kontribusinya dalam Pembentukan Karakter Siswa SMA. Ranah: Jurnal Kajian Bahasa. https://doi.org/10.26499/rnh.v7i1.580

Mat, Z., \& Sulaiman, M. (2007). Interaksi budaya India \& Cina ke atas pengukuhan bahasa dalam Tamadun Melayu. Jurnal Pengajian Umum.

Melebek, A. R. (2006). Sejarah Bahasa Melayu. Malaysia: Utusan Publications.

Nasanius, Y. (2007). Universitas Katolik Indonesia Atma Jaya. Pusat Kajian Bahasa dan Budaya Atma Jaya: kedelapan belas. Jakarta: Yayasan Obor Indonesia.

Pateda, M. (1988). Pateda, Mansoer. (1988). Linguistik Sebuah Pengantar. Bandung: Angkasa.

Peiros, I. (1998). Comparative linguistic in Southeast Asia. In Pacific Linguistics Series C (Vol. 142). Canberra: Australia National University.

Pinem, M. (2018). Inskripsi Islam pada Makam-Makam Kuno Barus. Jurnal Lektur Keagamaan.

https://doi.org/10.31291/jlk.v16i1.484

Proudfoot, I. (1993). Early Malay printed books. A Provisional Account of Materials Published in the Singapore-Malaysia Area up to 1920, Noting Holdings in Major Public Collections, 28. 
Purwanto, B. (2002). Ekonomi Masa Kolonial, Ensiklopedi Tematis Dunia Islam, Asia Tenggara. Jakarta: PT Ichtiar Baru Van Hoeve.

Ramli, Z., \& Sulaiman, Z. (2017). Penutur Austronesia Dan Cara Penyebarannya: Pendekatan Arkeologi, Genetik dan Linguistik. Arkeologi Malaysia, 30(2), 5974.

Sapir, E. (1939). Language: An introduction to the study of speech. New York: Harcourt.

Sapir, E. (1968). Time perspectives in original American Culture: A study in method. In In David G. Mandelbaum (eds). Selected writings of Edward Sapir in language, culture and personality ( $\mathrm{pp}$. 389-467). Berkeley, CA: University of California Press.

Sariyan, A. (2006). Kajian bahasa dan linguistik Melayu di Malaysia: perkembangan dan hala tuju masa hadapannya. In Insular Southeast Asia: Linguistic and Cultural Studies in Honour of Bernd Nothofer (pp. 53-64).

Supriono, I. A. (2015). Islam di Nusantara dan Transformasi Kebudayaan Melayu Indonesia. Madania, 5(2), 177-199.

Suryanegara, A. M. (1995). Menemukan sejarah: wacana pergerakan Islam di Indonesia. Bandung: Mizan.

Teeuw, A. (1994). Indonesia: antara kelisananan dan keberaksaraan. Jakarta: Pustaka Jaya.

Thurgood, G. (1996). Language contact and the directionality of internal drift: the development of tones and registers in Chamic. Language, 1-31.

Tjandrasasmita, U. (2002). Kedatangan dan Penyebaran Islam, Ensiklopedi Tematis Dunia Islam, Asia Tenggara. Jakarta: PT Ichtiar Baru Van Hoeve.

Tuuk, H. N. V. D. (1856). Iets over de Hoog-Maleische
[Something about the High Malay Bible translation]. Tijdschrift van Het Delftsch Instituut, 171-183.

Verhaar, J. W. . (1984). Pengantar Linguistik. Yogyakarta: Gajah Mada University Press.

Wolters, O. . (2017). Kebangkitan dan Kejayaan Sriwijaya Abad III-VII. Jakarta: Komunitas Bambu.

Yatim, B. (2010). Sejarah Peradaban Islam. Jakarta: PT Raja Grafindo. 